Acta vet. scand. $1973,14,205-218$.

From The State Veterinary Institute for Virus Research, Lindholm, Kalvehave, Denmark.

\title{
DIAGNOSIS OF MIXED INFECTIONS WITH MYXOVIRUS INFLUENZAE A EQUI 2 AND HERPES VIRUS EQUI 1 AMONG DANISH STUD HORSES
}

\author{
By \\ Kurt Jensen
}

\begin{abstract}
JENSEN, KURT: Diagnosis of mixed infections with Myxovirus influenzae $A$ equi 2 and Herpes virus equi 1 among Danish stud horses. Acta vet. scand. 1973, 14, 205-218. - Examination of nasopharyngeal secretion and organ material from clinical cases of respiratory diseases in horses, using inoculation of embryonated hen eggs and rabbit and horse kidney cell cultures, resulted in the isolation of influenza virus and herpes virus. In 2 cases, both viruses were present in the same specimen.

On the basis of the physio-chemical, cytological and serological criteria, the viruses were found to be identical with influenza virus type A equi 2 and herpes virus equi type 1 .

The methods for serological diagnosis and characterization of the influenza and herpes viruses are discussed. Detailed serological examinations of blood specimens from the clinical cases confirmed the aetiological significance of the isolates and the presence of mixed infections.

Further characterization of a strain of influenza virus was carried out by inoculation experiments on horses. These included reproduction of clinical influenza, reisolation of the strain in casu and a study of the antibody formation.
\end{abstract}

mixed respiratory virus infections; influenza; herpes; is olation; emb. hen eggs; kidney cell cultures; serology; type and subtypedetermination; $\mathrm{K} \mathrm{b}$; $\mathbf{H ~ I}$.

Since the isolation of the 2 equine influenza virus subtypes A/equi 1/Prague in 1956 and A/equi 2/Miami in 1963 (Sovinova et al. 1958, Waddel et al. 1963), a number of strains of both subtypes have been found in several countries. Their global distribution has been reported in a survey by McQueen et al. (1968). 
Complement fixing antibodies against human influenza virus type A antigen were found in horse sera in Sweden in 1955 ( $\mathrm{Hel}$ ler et al. 1956), and subsequently antibodies against both subtypes have been demonstrated in Swedish and Danish stud horses (Espmark \& Salenstedt 1964, Rasmussen 1968). A recent study from Italy reports the isolation of an equine influenza $B$ virus (Compagnucci et al. 1969). On account of the lability of influenza virus antigen, type and subtype diagnosis cannot be based on serology alone, but must be combined with virological methods.

Catarrhal respiratory conditions in horses can also be caused by a number of other viruses than influenza virus. Manninger \& Csontos (1941) showed that the abortogenic agency, by Doll et al. (1957) called rhinopneumonitis virus and later by Plummer \& Waterson (1963) classified as herpes virus equi type 1 , could cause slight catarrhal respiratory infections. During epizootic outbreaks of infectious arteritis, Doll et al. isolated equine arteritis virus from abortion material, and Bürki (1965) from nasoconjunctival secretion. Ditchfield et al. (1963) isolated Myxovirus parainfluenzae 3 from catarrhal respiratory diseases, and furthermore reports are available of the isolation of equine rhinovirus (Plummer 1962, Ditchfield \& Macpherson 1965).

Since the virus infections mentioned cannot be clinically distinguished from each other, laboratory methods must be employed to ensure definite diagnosis. In order to achieve the best results, the author has included inoculation of embryonated hen eggs and of rabbit and horse kidney cell cultures. The significance of this procedure is supported by own results, as well as by the mixed infections with herpes and influenza virus reported by Bürki (1966).

\section{Isolation of virus}

\section{METHODS}

Nasopharyngeal secretion from clinical cases of respiratory affections was taken by means of a dry, sterile cotton swab fixed to a plastic drain. This was inserted via the ventral meatus of the nose into the nasopharyngeal cavity, where the swab can absorb about $1 \mathrm{~g}$ of secretion within a few moments. The swabs were transported to the laboratory in refrigerated condition in a small vial containing $4 \mathrm{mg}$ streptomycin, $4 \mathrm{mg}$ neomycin, 4.000 i.u. penicillin, 4.000 i.u. mycostatin, and $100 \mathrm{mg}$ ovalbumin dis- 
solved in $3 \mathrm{ml}$ physiological saline buffer, $\mathrm{pH}$ 7.2. In accordance with standard prescriptions (Maramorosch \& Koprowski 1967) the material, i.e. the nasal secretion or a $10 \%$ organic suspension in physiological saline buffer with antibiotics, was inoculated into the amniotic and allantoic cavity of embryonated hen eggs and into primary rabbit and low passaged horse kidney cell cultures. Each specimen was taken through at least 3 passages, and the virus multiplication was determined by evaluation of haemagglutination, haemadsorption and cytopathogenic change in the cultures.

\section{Preparation of antigens}

Soluble influenza antigen ( $S$ antigen) for type specific complement fixation was made from chorioallantoic membranes harvested 6 hrs. after inoculation with $0.2 \mathrm{ml}$ per egg of undiluted allantoic fluid containing virus. The $S$ antigens were extracted and treated in accordance with the technique of Lief \& Henle (1959).

Influenza virus antigen ( $\mathrm{V}$ antigen) for subtype specific complement fixation was also prepared by a technique described by Lief $\&$ Henle. However, in contrast to human influenza A strains, it proved necessary to prolong the elution time for the equine strains from $2 \times 6$ to $2 \times 8 \frac{1}{2} \mathrm{hrs}$. in order to achieve maximum antigen yield.

Influenza antigen for use in the haemagglutination test was produced by inoculating 10-day-old embryonated hen eggs with $0.2 \mathrm{ml}$ allantoic fluid containing virus, diluted $10^{4}$ times and harvested after incubation at $35^{\circ} \mathrm{C}$ for $44-48 \mathrm{hrs}$.

Herpes virus equi type 1 antigen for complement fixation and neutralization tests was produced in primary rabbit cell cultures. The virus was harvested when $75-90 \%$ cytopathogenic changes were visible and $10 \%$ heat-treated calf serum was added. The cells were disintegrated by freezing and the cell remnants were removed by centrifugation.

\section{Production of sera}

Haemagglutination inhibiting sera were produced on chickens by 2 intravenous injections at an interval of 4 weeks, using $5 \times 10^{3}$ haemagglutinating virus units adsorbed to chicken erythrocytes. Blood specimens were taken 3 weeks after each injection, and blood from groups of 3 chickens was pooled. 
Complement fixing and haemagglutination inhibiting sera were prepared on 2 horses infected by inhalation of an aerosol containing virus. Further immunization was performed by intravenous injection of virus (see section concerning experimental horses). The course of the immunization was observed by examination of blood specimens taken weekly.

\section{Serological technique}

Haemagglutination inhibition test (HI test) was performed with 4 haemagglutinating virus units in $0.25 \mathrm{ml}$ diluent +0.25 ml two-fold serum dilutions $+0.25 \mathrm{ml} 0.5 \%$ chicken erythrocyte suspension. After being allowed to stand for $1 \mathrm{hr}$. at room temperature, the serum-antigen mixtures were added the erythrocyte suspension, and reading of $100 \%$ inhibition was made after a further $90 \mathrm{~min}$. at room temperature. A haemagglutinating unit is defined, here, as the amount of agglutinin which in $0.5 \mathrm{ml}$ fluid can agglutinate $0.25 \mathrm{ml} 0.5 \%$ chicken erythrocyte suspension in the course of $90 \mathrm{~min}$. at room temperature. The diluent was physiological saline buffer, pH 7.2. Chicken serum was heattreated at $56^{\circ} \mathrm{C}$ for $30 \mathrm{~min}$., while horse serum was incubated with trypsin at $37^{\circ} \mathrm{C}$ for $30 \mathrm{~min}$. and treated with potassium periodate in order to remove unspecific haemagglutination inhibitors (Harris 1964).

The complement fixation test was performed with $4-6$ units of antigen, depending on the form of the fixation curve determined by block titration, two-fold serum dilutions, 2 units of complement, 2 units of haemolysin and $2 \%$ sheep erythrocyte suspension. After dilution in veronal buffer (Schjerning-Thiesen 1964), the total volume of each component used was $0.1 \mathrm{ml}$. Fixation was carried out at $4^{\circ} \mathrm{C}$ for $18 \mathrm{hrs}$., followed by $30 \mathrm{~min}$. at $37^{\circ} \mathrm{C}$ with haemolytic system and visual colorimetric reading with $50 \%$ fixation as criterion after standing for $1 \mathrm{hr}$. at room temperature. Complement in horse serum was inactivated at $56^{\circ} \mathrm{C}$ for $30 \mathrm{~min}$.

\section{Isolates}

\section{RESULTS}

Nasopharyngeal secretion from 3 horses in herds $B$ and C, together with lung tissue taken from 1 foal in herd $A$, were inoculated into embryonated hen eggs, and resulted in isolation 
T a ble 1. Determination of influenza virus types by cross complement fixation tests.

\begin{tabular}{lrr}
\hline $\begin{array}{c}\text { S antigens } \\
\text { (4 units) }\end{array}$ & \multicolumn{2}{c}{ Reference sera* } \\
\cline { 2 - 3 } & influenza A & influenza B \\
\hline influenza A & 64 & 8 \\
influenza B & 0 & 128 \\
strain A 402 & 64 & 4 \\
strain B 30 & 32 & 8 \\
strain C 5 & 32 & 8 \\
strain C 7 & 64 & 8 \\
\hline
\end{tabular}

* Serum titres expressed as reciprocal values.

Lowest serum dilution investigated 1:2.

of 4 haemagglutinating agents. The isolates were designated with the letter of the herd and the serial number of the horse, viz. B 30, C 5, C 7 and A 402. It was not possible by culturing test material on rabbit and horse kidney cell cultures to demonstrate haemadsorbing ability in the cells or haemagglutinins in culture medium with guinea pig and chicken erythrocytes. Furthermore, the specimens from foal A 402 and horse C 7 did not evoke a cytopathogenic effect in rabbit and horse kidney cell cultures. However, the specimens from horses B 30 and C 5 showed marked cytopathogenicity against both cell types as early as the first passage. This took the form of progressive development of rounded cell groups with increased refractivity. Similar cytopathogenic strains were isolated from horses A 429, C 1, C 2 and C 4. These are numbered as mentioned above, with the addition of " $\mathrm{C}$ " after the number of the horse.

\section{Virus identification}

The fact that the cytopathogenic antigens did not induce development of haemagglutinins in hen eggs and that the third egg passage of the haemagglutinating antigens is not cytopathogenic in rabbit and horse kidney cell cultures, seems to indicate that 2 different groups of isolates are involved.

The cytopathogenic strains were found to be sensitive to $10 \%$ chloroform at room temperature for $10 \mathrm{~min}$., they developed intranuclear type $A$ inclusion bodies in both cell types and were 
Table 2. Determination of influenza virus subtype by cross haemagglutination inhibition tests.

\begin{tabular}{|c|c|c|c|c|c|c|c|c|c|c|}
\hline \multirow{3}{*}{$\begin{array}{l}\text { Haemagglutinating } \\
\text { antigens (4 units) }\end{array}$} & \multicolumn{10}{|c|}{ Chicken reference sera ${ }^{*}$} \\
\hline & \multicolumn{2}{|c|}{$\begin{array}{l}\text { equi } 1 \\
\text { Prague }\end{array}$} & \multicolumn{2}{|c|}{$\begin{array}{c}\text { equi } 1 \\
\text { Cambridge }\end{array}$} & \multicolumn{2}{|c|}{$\begin{array}{l}\text { equi } 2 \\
\text { Miami }\end{array}$} & \multicolumn{2}{|c|}{$\begin{array}{l}\text { strain } \\
\text { A } 402\end{array}$} & \multicolumn{2}{|c|}{$\begin{array}{c}\text { strain } \\
\text { B } 30\end{array}$} \\
\hline & $\mathbf{a}$ & b & $\mathbf{a}$ & b & $\mathbf{a}$ & b & $\mathbf{a}$ & b & $\mathbf{a}$ & b \\
\hline equi $1 /$ Prague & 640 & 5120 & 640 & 5120. & 0 & 0 & 0 & 0 & 0 & 0 \\
\hline equi 1 /Cambridge & 1280 & 5120 & 1280 & 2560 & 0 & 0 & 0 & 0 & 0 & 0 \\
\hline equi 2 /Miami & 0 & 0 & 0 & 0 & 160 & 1280 & 40 & 640 & 80 & 1280 \\
\hline strain A 402 & 0 & 0 & 0 & 0 & 160 & 1280 & 80 & 640 & 80 & 1280 \\
\hline strain B 30 & 0 & 0 & 0 & 0 & 80 & 1280 & 40 & 1280 & 80 & 1280 \\
\hline strain $C_{5}$ & 0 & 0 & 0 & 0 & 160 & 1280 & 40 & 1280 & 80 & 1280 \\
\hline strain $\mathrm{C} 7$ & 0 & 0 & 0 & 0 & 160 & 1280 & 80 & 1280 & 80 & 1280 \\
\hline
\end{tabular}

* Serum titres expressed as reciprocal values.

Lowest serum dilution investigated 1:5.

a: 3 weeks after first inoculation.

b: 3 weeks after second inoculation.

neutralized by a rabbit antiserum against herpes virus equi type 1 .

Since the haemagglutinating strains did not induce haemadsorption or cytopathogenicity, efforts were made to identify them as influenza virus. The type was determined with $\mathrm{S}$ antigens from the strains in casu and influenza virus types $A$ and $B^{*}$ by cross complement fixation test with a type $A$ complement fixing equine convalescent serum and a type $B$ complement fixing human convalescent serum. It will be seen from Table 1 that the 4 isolates reacted with influenza virus type $A$ with titres $1: 32$ to 1:64, i.e. significantly. However, type $B$ serum reacted only slightly with the isolates.

Furthermore, the subtype of the influenza virus types isolated was determined by using the antigens * and chicken immune sera shown in Table 2 . It will be seen from the table that all 4 strains could be identified antigenically as influenza virus $\mathrm{A} /$ equi 2/Miami. It will also be seen from the table that the high titred chicken sera produced after 2 immunizations caused no unspecific reactions between the equi 1 and equi 2 groups.

* Type $B$ influenza $S$ antigen and reference serum were kindly supplied by Dr. C. H. Mordhorst, Statens Seruminstitut, Copenhagen.

* The author is grateful to Dr. H. G. Pereira, World Influenza Centre, London, for supplying the influenza A equi prototypes. 
Origin of the influenza equi and herpes equi strains and the aetiological significance of the clinicat cases observed

Herd A. Influenza virus strain 4402 and herpes virus strain $A 429 / C$. During an outbreak of clinical influenza in a large herd of horses, a mare (A 14) with a slight attack of the disease gave birth to a foal at full term. Two days after birth the fully-developed foal had elevated temperature and symptoms of pneumonia. It died at the age of 1 week. Examination was made of liver, spleen and lung tissue, and from the lung tissue only it was possible to isolate the influenza virus strain A 402. On the death of the foal, blood specimens were taken from mares A 12 and A 13 and again after 4 and 9 weeks. Blood was also taken from the mother mare $A 14$ at 9 weeks. About 1 month after the death of the foal, a case of abortion occurred in the herd, and a strain of herpes virus A 429/C was isolated from liver, spleen and lung tissue.

The coincidental occurrence of influenza $A$ equi 2 and herpes equi 1 was also reflected by the serological findings (Table 3 ). In all blood specimens there was a high content of complement fixing antibodies against herpes virus, whereas antibodies against influenza virus $A$ equi 2 could not be demonstrated in serum during the acute phase of the disease. However, the latter could be found clearly in the specimens taken 4 weeks later. This confirms that both agents had been present in the herd, presumably firstly as a subclinical herpes equi infection complicated by abortion, and later as fatal clinical influenza in a foal.

Herd B. Influenza virus strain $B 30$ and herpes virus strain $B 30 / C$. From the nasopharyngeal secretion of a one-month-old foal B 30 with clinical symptoms of respiratory infection, an influenza virus strain $B 30$ and a herpes virus strain $B$ 30/C were isolated. The mother mare B 29 showed no signs of disease, but it was known that in the period before specimens were sent in, there had been slight signs of colds in some of the horses in the herd.

Serological examination of blood specimens, taken simultaneously with the nasopharyngeal secretion and after 4 and 9 weeks (Table 3), showed that already in the first specimens there was a considerable content of complement fixing antibodies against herpes virus. However, influenza virus $A$ equi 2 antibodies were first demonstrable in the period between the first 
and second specimen taken. Thus, the herpes infection occurred first and persisted during the infection with influenza virus.

Herd $C$. Influenza virus strains $C 5$ and $C 7$ and herpes virus strains $C 1 / C, C 2 / C, C 4 / C$ and $C 5 / C$. After about 12 hrs. contact between the animals in a herd of 7 foals collected for slaughtering and about 5 months old (Nos. C 1, C 2, etc.), nasopharyngeal secretion and blood specimens were taken from all animals. Foals C 1 and C 4 had open strangles abscesses of longer duration and were therefore removed from the herd immediately after the specimens were taken. As mentioned, influenza virus strains $\mathbf{C} 5$ and $C 7$ and herpes virus strains $C 1 / C, C 2 / C, C 4 / C$ and $C 5 / C$ were isolated by culture. After a few days, symptoms of respiratory infection were observed, and varying degrees of fever, cough, serous and later mucopurulent nasal discharge developed in the remaining 5 foals. Three of these, viz. C 2, C 3 and C 6, developed definite strangles abscesses in the course of $2-3$ weeks, and streptococcus equi was found in pus from C 2.

After 4 weeks, new nasopharyngeal secretion and blood specimens were taken. Herpes virus was isolated by culture from C 2, but otherwise the results were negative. C 2 was slaughtered 5 months later, and cell degeneration typical for herpes virus was found in primary cell cultures from 1 of the kidneys. It must be assumed, therefore, that the foal had had a persisting infection. Serological examination, including blood specimens taken after 9 weeks (Table 3 ), showed that the herd had been subjected to a mixed infection with herpes virus equi type 1 and influenza virus $A$ equi 2, complicated by clinically recognizable strangles in 3 of the foals.

\section{Inoculation of horses}

Further attempts to identify the influenza virus strain $\mathbf{A} 402$ were made by inoculation of horses. 'Two horses aged about 18 months (I and II) were infected by inhalation of an aerosol prepared from $10 \mathrm{ml} 20 \%$ lung tissue suspension from foal A 402. On the day after inoculation, both horses were febrile. Maximum temperatures $\left(40.3^{\circ} \mathrm{C}\right.$ and $40.0^{\circ} \mathrm{C}$ ) were noted on the second day after infection, and after 4 days the temperature was again normal. Both horses were slightly subdued and had strongly increased pulse and respiration rates on the second day after infection. Furthermore, they had serous nasal discharge 
T a b le 3. Serological investigations in herds A, B and C.

\begin{tabular}{|c|c|c|c|c|c|c|c|c|c|c|c|c|c|c|c|c|c|c|}
\hline \multirow{4}{*}{$\begin{array}{l}\text { Horse } \\
\text { no. }\end{array}$} & \multicolumn{9}{|c|}{ Complement fixation } & \multicolumn{6}{|c|}{ Haem. Inhibition } & \multicolumn{3}{|c|}{ Compl. fixation } \\
\hline & \multicolumn{3}{|c|}{$S$ antigens } & \multicolumn{6}{|c|}{$V$ antigens } & & & & & & & & & \\
\hline & \multicolumn{3}{|c|}{ influenza $A$} & \multicolumn{3}{|c|}{$\begin{array}{l}\text { equi } 1 \\
\text { Prague }\end{array}$} & \multicolumn{3}{|c|}{$\begin{array}{r}\text { equi } 2 \\
\text { A } 402\end{array}$} & \multicolumn{3}{|c|}{$\begin{array}{l}\text { equi } 1 \\
\text { Prague }\end{array}$} & \multicolumn{3}{|c|}{$\begin{array}{l}\text { equi } 2 \\
\text { A } 402\end{array}$} & \multicolumn{3}{|c|}{$\begin{array}{c}\text { herpes equi } \\
\text { type } 1\end{array}$} \\
\hline & $\bar{a}$ & b & c & $\mathbf{a}$ & $\mathbf{b}$ & c & $\mathbf{a}$ & $\mathbf{b}$ & c & $\mathbf{a}$ & b & $\bar{c}$ & $\bar{a}$ & b & c & a & b & c \\
\hline A 12 & $0^{*}$ & 32 & 16 & 2 & 16 & 8 & 0 & 64 & 16 & 80 & 80 & 80 & 0 & 80 & 80 & 128 & 128 & 256 \\
\hline A 13 & $\mathbf{0}$ & 256 & 64 & 0 & 16 & 8 & 0 & 64 & 32 & 80 & 160 & 80 & $\mathbf{0}$ & 80 & 80 & 64 & 128 & 128 \\
\hline A 14 & - & - & 64 & - & - & 32 & - & 一 & 64 & 一 & - & 160 & 一 & - & 160 & - & 一 & 256 \\
\hline B 29 & 0 & 64 & 8 & 0 & 2 & 0 & 0 & 128 & 32 & 80 & 80 & 40 & 80 & 80 & 80 & 64 & 128 & 32 \\
\hline B 30 & 0 & 32 & 4 & 0 & 2 & 0 & 0 & 256 & 32 & 0 & 20 & 20 & 0 & 40 & 40 & 16 & 16 & 16 \\
\hline C 1 & 0 & - & - & 2 & - & - & 8 & - & - & 80 & - & - & 10 & - & - & 4 & - & - \\
\hline C 2 & 0 & 0 & 0 & 0 & 0 & 0 & 16 & 8 & 16 & 160 & 640 & 320 & 40 & 160 & 160 & 0 & 16 & 16 \\
\hline C 3 & 0 & 8 & 0 & 0 & 4 & 0 & 0 & 16 & 8 & 160 & 640 & 160 & 40 & 320 & 80 & 64 & 32 & 8 \\
\hline C 4 & 0 & - & - & 2 & - & - & 128 & - & - & 20 & - & - & 20 & - & - & 32 & - & - \\
\hline C 5 & 0 & 0 & 0 & 0 & 16 & 0 & 0 & 32 & 4 & 80 & 320 & 160 & 40 & 160 & 160 & 16 & 32 & 8 \\
\hline C 6 & 0 & 4 & 4 & 0 & 0 & 0 & 0 & 32 & 16 & 320 & 160 & 320 & 160 & 320 & 320 & 0 & 16 & 8 \\
\hline C 7 & 0 & 256 & 64 & 0 & 4 & 0 & 0 & 256 & 64 & 40 & 80 & 80 & 10 & 80 & 80 & 0 & 32 & 16 \\
\hline
\end{tabular}

- Serum titres expressed as reciprocal values.

CF: lowest serum dilution investigated 1:2.

HI: $" \quad " \quad " \quad 1: 10$.

a: acute disease.

b: 4 weeks later.

c: 9 " "

-: not investigated.

T a b l e 4. Serological results after repeated inoculation of influenza $A$ viruses in 2 experimental horses (I and II).

\begin{tabular}{|c|c|c|c|c|c|c|c|c|c|c|c|c|}
\hline & \multicolumn{10}{|c|}{ Horse I serum } & \multirow{2}{*}{\multicolumn{2}{|c|}{$\begin{array}{l}\text { Horse II } \\
\text { serum } \\
\text { inoc. equi } \\
\text { 2/A } 402\end{array}$}} \\
\hline & \multicolumn{6}{|c|}{ inoc. equi 2/A 402} & \multicolumn{4}{|c|}{ inoc. equi $1 /$ Prague } & & \\
\hline & i.n. & & i.n. & & 1.v. & & i.v. & & i.v. & & i.n. & \\
\hline $\begin{array}{l}\text { CF } S \text { antigen } \\
\text { infl. type } A\end{array}$ & $0^{*}$ & 32 & 16 & 16 & 16 & 32 & 8 & 64 & 64 & 128 & $\mathbf{0}$ & 128 \\
\hline CF $V$ antigen & & & & & & & & & & & & \\
\hline equi $1 /$ Prague & $\mathbf{0}$ & $\mathbf{0}$ & 0 & 0 & 0 & 0 & 8 & 128 & 32 & 256 & 0 & $\mathbf{0}$ \\
\hline CF $\mathrm{V}$ antigen & & & & & & & & & & & & \\
\hline equi $2 /$ A 402 & 32 & 64 & 32 & 32 & 32 & 1024 & 128 & 64 & 64 & 64 & 32 & 64 \\
\hline HI equi 1/Prague & $\mathbf{0}$ & 0 & 0 & 0 & $\mathbf{0}$ & $\mathbf{0}$ & 0 & 40 & 0 & 320 & 0 & $\mathbf{0}$ \\
\hline HI equi 2/A 402 & 0 & 80 & 80 & 160 & 80 & 640 & 160 & 80 & 160 & 160 & 0 & 80 \\
\hline $\begin{array}{c}\text { Days after first } \\
\text { inoculation }\end{array}$ & $\mathbf{0}$ & 21 & 35 & 56 & 63 & 84 & 126 & 147 & 175 & 186 & $\mathbf{0}$ & 21 \\
\hline
\end{tabular}

- Serum titres expressed as reciprocal values.

CF: lowest serum dilution investigated 1:2.

HI: $" \quad " \quad$ " $1: 10$. 
and a dry, hard cough 7-9 days after infection. The course of the disease in both horses was otherwise without complications. Isolation of influenza virus type A equi 2 from horse II took place 3 days after infection. The moderate but typical course of disease, together with the serological (Table 3) and virological findings, show that the lung tissue from foal A 402 contained influenza virus type A equi 2 . Both before and after reproduction of clinical influenza, sera from both horses were examined for complement fixing antibodies against herpes virus type 1 . In all cases the serological titres were less than $1: 2$.

The humoral antibody titre was observed in horse $I$ in connection with several reinfections (Table 4). Thirty-five days after the primary inoculation, this was repeated with an analogous aerosol. No clinical symptoms or increase of antibody titres occurred. Sixty-three days after the primary inoculation, $10^{4}$ haemagglutinating virus units of strain A 402 adsorbed to horse erythrocytes were administered intravenously. This procedure was repeated with $A$ equi 1/Prague after a further 126 and 175 days. No clinical symptoms were observed. That type A equi 1/Prague did not evoke clinical symptoms but only caused antibody formation is probably due to the fact that it was a high passaged egg strain.

\section{DISCUSSION AND CONCLUSION}

It is generally not possible to make an aetiologically correct diagnosis of equine respiratory viruses on the basis of anamnestic informations and acute clinical symptoms. To follow the development of disease by means of evaluation of epizootological data increases the chances of diagnosis, but a specific diagnosis can only be established after laboratory examination of relevant material for content of virus and/or specific antibodies. In accordance with these guiding principles, the present study gives a report of the diagnostic results obtained from horses with respiratory affections in 3 herds.

Four serologically identical influenza virus A equi 2 strains were isolated (Tables 1 and 2), two of which originated from specimens which also contained herpes virus equi type 1 . It will be seen from the serological examinations (Table 3 ) that both types of agents caused immunological response in the infected 
animals, thus indicating mixed infections. Taking into account that herpes virus is found frequently, such cases can be expected to occur often.

Attempts were made to demonstrate serum antibodies against influenza virus in various ways (Tables 3 and 4 ). Type A complement fixing antibodies can be demonstrated without difficulty and can be used to determine preliminarily whether it is a question of a type $A$ infection, i.e. with serum from the acute and convalescent phases of the disease. Reports are available from human medicine of only weak or even no development of type A complement fixing antibodies in children below the age of 2 years and in vaccinated individuals (Hoyle 1968). An analogous situation was found in foals $\mathrm{C} 1$ to $\mathrm{C} 6$, since type $A$ complement fixing antibodies could only be demonstrated in insignificant numbers using $S$ antigen, in spite of the development of complement fixing antibodies against $\mathrm{V}$ antigen. However, foal $\mathrm{C} 7$, which was about 6 months older than the others, produced considerable numbers of serum antibodies against both complement fixing antigens.

Subtype specific serum antibodies were demonstrated with haemagglutinating and $V$ complement fixing antigens. Many studies on equine influenza have been carried out with the HI test exclusively. However, because of the risk of a heterologous anamnestic antibody response (Davenport \& Hennessy 1956) and an often quite considerable content of unspecific haemagglutination inhibitors in horse serum (Rice 1968) which available techniques cannot eliminate with certainty, the HI test may in some cases give unconclusive results (Table 3 ). It should therefore be supplemented by a subtype specific complement fixation test using $\mathrm{V}$ antigen. This may also involve problems with unspecific reactions such as, for example, in the horses in Table 4. Here the reaction with $\mathrm{V}$ equi 2 antigen was not due to persisting antibodies, since the $\mathrm{V}$ complement fixing antibodies disappear from the blood stream before the HI antibodies (Beveridge \& Rose 1967). Furthermore, a certain heterologous antibody response may be observed, such as that seen in horses $A 12$ and $A 13$ in Table 3. An analogous situation is described in the works of Paccaud et al. (1966) and Paccaud (1969), where it was concluded that the 2 tests performed simultaneously almost always give conclusive results from the aetiological point of view, provided the proper antigens are used. 
Serum antibodies against herpes virus equi type 1 are demonstrated by using the complement fixation test, because complement fixing antibodies occur in connection with fresh infections and persist for a shorter time than neutralizing antibodies. The complement fixation test, performed here with crude virus as antigen, did not differentiate between subtypes 1 and 2 . It is not yet clear whether cross reaction can take place with antibodies against other equine herpes virus (Erasmus 1969).

\section{REFERENCES}

Beveridge, W. I. B. \& M. A. Rose: Influenza in horses: Persistence of antibody measured by three methods. Brit. vet. J. 1967, 123, 8-13.

Bürki, F.: Eigenschaften des Virus der equinen Arteritis. (Properties of equine arteritis virus). Path. et Microbiol. (Basel) 1965, 28, $939-949$.

Bürki, F.: Epizootiology of several equine virus infections present in Central Europe. Proc. 1st Int. Conf. Equine Infectious Diseases. Stresa 1966, 89-93. Grayson Foundation, Lexington, Ky. 1968.

Compagnucci, M., E. Martone \& A. Bonaduce: Influenza del cavallo da Myxovirus influenzae tipo B. Nota I. Caratteristich e dei ceppi isolati. (Equine Myxovirus influenzae group B. Identification of two strains). Boll. Ist. sieroter. milan. 1969, 48, 305-316.

Davenport, F. M. \& A. V. Hennessy: A serologic recapitulation of past experiences with influenza A; Antibody response to monovalent vaccine. J. exp. Med. 1956, 104, 85-97.

Ditchfield, J., A. Zbitnew \& L. W. Macpherson: Association of Myxovirus parainfluenzae 3 ( $R E$ 55) with upper respiratory infection of horses. Canad. vet. J. 1963, 4, 175-180.

Ditchfield, J. \& L. W. Macpherson: The properties and classification of two new rhinoviruses recovered from horses in Toronto, Canada. Cornell Vet. 1965, 55, 181-189.

Doll, E. R., J. T. Bryans, W. H. McCollum \& M. E. W. Crowe: Isolation of a filtrable agent causing arteritis of horses and abortion by mares: Its differentiation from equine abortion (Influenza) virus. Cornell Vet. 1957, 47, 3-41.

Erasmus, B. J.: Equine cytomegaloviruses. Proc. 2nd Int. Conf. Equine Infectious Diseases. Paris 1969, 46-55. S. Karger Verlag, Basel 1970.

Espmark, J. A. \& C. R. Salenstedt: Outbreaks of equine influenza A in Sweden in 1960. Nord. Vet.-Med. 1964, 16, 910—921.

Harris, R. J. C.: Techniques in experimental virology. Acad. Press, New York - London 1964. 
Heller, L., A. Espmark \& P. Viridèn: Immunological relationship between infectious cough in horses and human influenza A. Arch. ges. Virusforsch. 1956, 7, 120-124.

Hoyle, L.: The Influenza Viruses. "Virology Monograph". Springer Verlag, Wien - New York 1968.

Lief, F. S. \& W. Henle: Methods and procedures for use of complement fixation techniques in type and strain-specific diagnoses of influenza. Bull. Wld Hith Org. 1959, 20, 411-420.

Manninger, R. \& J. Csontos: Virus Abortus der Stuten. (Viral abortion by mares). Dtsch. tierärztl. Wschr. 1941, 49, 105-108.

Maramorosch, K. \& H. Koprowski: Methods in Virology. Acad. Press, New York - London 1967.

McQueen, J. L., J. H. Steele \& R. Q. Robinson: Influenza in animals. Advanc. vet. Sci. 1968, 12, 285-336.

Paccaud, M. F.: The virology of equine influenza. Proc. 2nd Int. Conf. Equine Infectious Diseases. Paris 1969, 81-93. S. Karger Verlag, Basel 1970.

Paccaud, M. F., F. Bürki \& H. Gerber: Influenza A/equi-2 in der Schweiz 1965. (Influenza A/equi-2 in Switzerland 1965). Zbl. Vet.-Med., Reihe B 1966, 13, 417-426.

Plummer, G.: An equine respiratory virus with enterovirus properties. Nature (Lond.) 1962, 195, 519-520.

Plummer, G. \& A. P. Waterson: Equine herpes viruses. Virology 1963, $19,412-416$.

Rice, C. E.: Comparative serology of domestic animals. Advanc. vet. Sci. 1968, 12, 105-162.

Rasmussen, P. G.: Epizootiological study of some respiratory virus infections (Herpes Equi, Influenza $A$ /Equi 1 and $A /$ Equi 2 and Parainfluenza-3 virus) in Danish stud horses. Nord. Vet.-Med. $1968,20,1-8$.

Schjerning-Thiesen, K.: Studier over komplementbinding. (Studies of complement fixation). Thesis, Copenhagen 1964.

Sovinova, O., B. Tumova, F. Pouska \& J. Nemec: Isolation of virus causing respiratory disease in horses. Acta virol. 1958, 2, 52-61.

Waddel, G. H., M. B. Teigland \& M. M. Siegel: A new influenza virus associated with equine respiratory disease. J. Amer. vet. med. Ass. 1963, 143, 587-590.

\section{SAMMENDRAG}

Diagnostiske resultater med blandingsinfektioner med Myxovirus influenzae $A$ equi 2 og Herpesvirus equi 1 i nogle danske hestebesætninger.

Fra nasopharyngealt sekret og organmateriale fra kliniske tilfælde af respirationsvejslidelser hos heste er der efter podning med materialet på embryonerede hønseæg og kanin- og hestenyrecellekulturer 
isoleret influenzavirus og herpesvirus. I to tilfælde påvistes begge virus i det samme prøvemateriale.

Ud fra fysisk-kemiske, cytologiske og serologiske kriterier er de to virus fundet identiske med influenzavirus type A equi 2 og herpesvirus equi type 1 .

Metoder til serologisk diagnostik og karakteristik af influenzavirus og herpesvirus diskuteres.

Med en influenzavirusstamme er der udført podningsfors $\varnothing \mathrm{g}$ på heste. Herunder fremkaldtes klinisk influenza, og virusstammen in casu isoleredes. Der udf $\varnothing$ rtes endvidere studier over antistofdannelsen.

(Received December 16, 1971).

Reprints may be requested from: Kurt Jensen, Department of Animal Nutrition, Royal Veterinary and Agricultural University, Bülowsvej 13, DK-1870 Copenhagen V, Denmark. 